\title{
KAJIAN PERANCANGAN RULE KENAIKAN JABATAN PADA PT. ABC
}

\author{
Harry Dhika \\ Fakultas Teknik, Matematika dan IPA \\ Universitas Indraprasta PGRI \\ Email: dhikatr@yahoo.com
}

\begin{abstract}
ABSTRAK
Penelitian ini membahas tentang cara membuat rule atau aturan menggunakan algoritma C4.5 terhadap kenaikan jabatan pada salah satu perusahaan swasta. Luaran dari penelitian ini adalah sebuah metode atau rule C4.5 (pohon keputusan) yang digunakan dalam penentu atau membantu mengambil keputusan serta menentukan kenaikan jabatan karyawan. Data dianalisis menggunakan perangkat lunak Rapidminer yakni salah satu perangkat lunak berbasis open source. Dalam menentukan kelayakan kenaikan jabatan pada perusahaan, digunakan metode penelitian Data Mining dengan framework KDD sehingga dapat diketahui tingkat akurasi dan presisinya. Dengan adanya hasil penelitian maka dapat memberikan konstribusi bagi instansi terkait untuk dapat melakukan pemilihan mitra kerja dengan baik dan tepat sasaran sehingga kesulitan dalam menentukan kelayakan kenaikan jabatan dapat teratasi, terutama masalah terkait pengalaman kerja, kualitas kerja, dan hal-hal lain.
\end{abstract}

Kata kunci: algoritma c4.5, data mining, kenaikan jabatan, rapidminer.

\section{ABSTRACT}

This study discusses about how to create a rule by using the C4.5 algorithm promotion on one private company. Outcomes of this research is a method or rule C4.5 (decision tree) are used in determining or help make decisions and determine employee promotions. Data were analyzed using the software RapidMiner one based on open source software. This study uses the concept of Data Mining with KDD framework so as to determine the feasibility of a promotion in the company to determine the level of accuracy and precision. With the research results can contribute to the relevant agencies to be able to work with a good selection of partners and targeted so that the difficulty in determining the feasibility of a promotion can be resolved, especially issues related work experience, quality of work, and other things.

Keywords: c4.5 algorithms, data mining, increase position, rapidminer.

\section{PENDAHULUAN}

Saat ini Sumber Daya Manusia (SDM) merupakan sebuah aset yang sangat berharga dan sangat strategis sehingga dapat menentukan sehat atau tidaknya sebuah perusahaan jika dilihat dari asetnya. Pengembangan sumber daya manusia tentunya harus terencana dan berkelanjutan hal tersebut merupakan kebutuhan perusahaan dimasa depan. Dalam perusahaan karyawan merupakan aset, sumber daya manusia yang harus dijaga dengan baik. Untuk menjaga sumber daya manusia maka dibutuhkan manajemen perencanaan, pengangkatan karyawan baru, melakukan seleksi, melakukan orientasi, melakukan pelatihan, pendidikan, penilaian kerja, dan melakukan promosi jabatan.

Perusahaan melakukan evaluasi atau melakukan penilaian terhadap seluruh karyawan, penilaian kerja pada karyawan (performance appraisal) merupakan bagian yang sangat penting karena dengan kualitas karyawan yang baik maka akan diperoleh hasil kerja yang baik. Target Perusahaan akan tercapai, kelangsungan perusahaan dan regenerasi dari karyawan dapat terlaksana dengan baik.

Seiring dengan menjaga aset, karyawan dalam perusahaan akan merasa nyaman jika diperlakukan dengan baik, adil dan jujur tentunya dengan mendapat peluang untuk diperhatikan dalam mengembangkan karir di perusahaan tersebut. Setiap karyawan pasti menginginkan penghargaan terutama promosi jabatan sehingga dapat bekerja dengan maksimal dan memajukan nama perusahaan. Dari hal tersebut perlunya dilakukan kajian mendalam sehingga kepuasan karyawan yang berujung majunya sebuah perusahaan dapat dijadikan sebagai dasar untuk membuat sebuah rule atau sistem informasi kenaikan atau promosi jabatan. PT. ABC merupakan sebuah perusahaan swasta nasional yang sangat aktif. Bergerak dibidang jasa pengiriman barang dan memiliki 28 cabang anak perusahaan sehingga banyak sekali dibutuhkan karyawan muda yang berprestasi dan berfikir kreatif. Perusahaan yang berada di tanah air ini menggunakan jalur darat, laut dan udara. Dengan karyawan yang tersebar dari sabang 
sampai marauke diperlukan tata kelola atau manajemen yang baik untuk menjaga aset perusahaan. Dalam perusahaan ini proses kenaikan jabatan atau promosi jabatan dilakukan dasarnya hanya bersifat kekeluargaan, karena mayoritas seluruh pimpinan di setiap wilayah merupakan karib kerabat yang dikedepankan. Dari hal tersebut dapat dilihat kurangnya profesionalisme kerja yang dapat membuat perusahaan kedepannya akan sulit berkembang dengan baik tanpa memperhatikan kejujuran kerja, masa kerja keahlian, disiplin dan usia. Proses kenaikan yang ada selama ini sangat dirasakan betul kurang efektif manfaatnya oleh karena itu perlunya perbaikan dalam sisi promosi jabatan.

Melihat dari situasi dan kondisi yang cukup memprihatinkan dimana perkembangan karir karyawan merupakan suatu hal yang penting dan harus diperhatikan oleh karena itu perlu dikaukan pengambilan keputusan [7] atau dilakukan kajian atau penelitian mendalam dengan menggunakan algoritma C4.5 dari Data Mining dan menggunakan metodologi Knowledge Discovery in Database (KDD). Pada penelitian ini pengambilan keputusan kenaikan jabatan menggunakan menggunakan metode algoritma C4.5 yang nantinya dalam pengolahan data akan dilakukan menggunakan software pendukung yaitu Rapidminer versi 5.1

Setiap lembaga atau perusahaan pasti bekerja dengan data, perusahaan yang sudah cukup lama tentunya juga memiliki data yang banyak, data dalam perusahaan tersebut semakin lama akan semakin menggunung atau semakin menumpuk dan disimpan tiap harinya, tiap bulannya dan tiap tahunnya. Tentunya data perusahaan tersebut sangat sayang sekali jika di buang, karena data tersebut merupakan aset berharga dari perusahaan apalagi jika data tersebut tidak digunakan sama sekali, untuk itu data yang jumlahnya sudah cukup banyak dan menggunung dapat digunakan kembali dengan cara menambangnya.

Data Mining atau menambang data didefinisikan sebagai metode yang digunakan untuk mengekstraksi informasi prediktif tersembunyi pada database, ini adalah teknologi yang sangat potensial bagi perusahaan dalam memberdayakan data warehouse-nya. Data Mining disebut sebagai proses ekstraksi pengertahuan dari data yang besar, sesuai fungsinya Data Mining adalah proses pengambilan keputusan dari volume data yang besar yang disimpan dalam basis data, data warehouse, atau informasi yang disimpan dalam repositori [2]. Istilah Data Mining berasal dari kemiripan antara pencarian informasi yang bernilai dari database yang besar dengan menambang sebuah gunung untuk memperoleh sesuatu yang bernilai [5]. Data Mining juga dapat didefinisikan sebagai sebuah proses penemuan pola dalam data [6]. Keduanya memerlukan penyaringan melalui sejumlah besar material, atau menyelidiki dengan cerdas untuk mencari keberadaan sesuatu yang bernilai. Berdasarkan polanya Data Mining dikelompokan menjadi deskripsi, estimasi, prediksi, klasifikasi, clustering, asosiasi [3]. Banyak yang menggunakan Data Mining sebagai istilah popular dari Knowledge Discovery in Database (KDD). Data Mining merupakan inti dari proses Knowledge Discovery in Database (KDD) [4]. KDD adalah proses terorganisir untuk mengidentifikasi pola yang valid, baru, berguna, dan dapat dimengerti dari sebuah data set yang besar dan kompleks [4].

Algoritma C4.5 merupakan algoritma klasifikasi dengan teknik pohon keputusan yang terkenal dan disukai karena memiliki kelebihan-kelebihan. Kelebihan ini misalnya dapat mengolah data numerik (kontinyu) dan diskret, dapat menangani nilai atribut yang hilang, menghasilkan aturan-aturan yang mudah diintrepetasikan dan tercepat diantara algoritma-algoritma yang lain. Keakuratan prediksi yaitu kemampuan model untuk dapat memprediksi label kelas terhadap data baru atau yang belum diketahui sebelumnya dengan baik. Dalam hal kecepatan atau efisiensi waktu komputasi yang diperlukan untuk membuat dan menggunakan model. Kemampuan model untuk memprediksi dengan benar walaupun data ada nilai dari atribut yang hilang. Dan juga skalabilitas yaitu kemampuan untuk membangun model secara efisien untuk data berjumlah besar (aspek ini akan mendapatkan penekanan). Terakhir interpretabilitas yaitu model yang dihasilkan mudah dipahami. Selain itu dapat juga dikatakan bahwa Algoritma merupakan kumpulan perintah yang tertulis secara sistematis guna menyelesaikan permasalahan logika dari matematika. Pengertian Algoritma C4.5 merupakan algoritma yang digunakan untuk membentuk pohon keputusan. Sedang pohon keputusan dapat diartikan suatu cara untuk memprediksi atau mengklarifikasi yang sangat kuat. Pohon keputusan dapat membagi kumpulan data yang besar menjadi himpunan-himpunan record yang lebih kecil dengan menerapkan serangkaian aturan keputusan

\section{METODOLOGI PENELITIAN}

Penemuan pengetahuan dari proses KDD yang terdiri dari sembilan langkah pada Gambar 1. Proses dimulai dari penentuan KDD dan diakhiri dengan pelaksanaan pengetahuan yang ditemukan. Penelitian dilakukan dengan menggunakan konsep dari Data Mining menggunakan Knowledge Discovery in Database (KDD) yakni sebuah kerangka kerja sebagai bahan acuan dalam pengkajian dibidang Data Mining: 


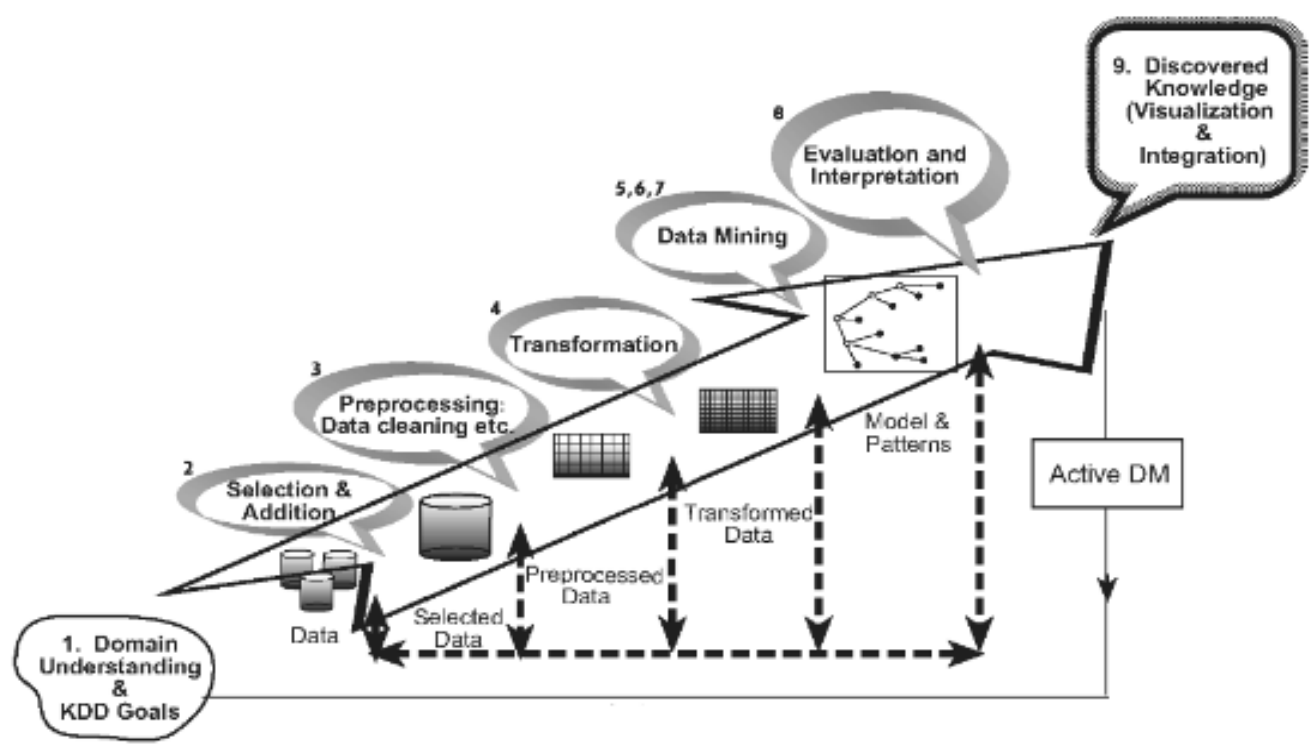

Gambar 1. Tahap KDD (Knowledge Discovery in Database) [4]

Metode dan tahapan penelitian menggunakan metode Knowledge Discovery in Database (KDD) yaitu meliputi; 1) Domain Understanding \& KDD Goal yakni dilakukan pemahaman terlebih dahulu hasil yang akan dicapai, bahasan dan bidang yang akan dikerjakan. 2) Selection \& Addition, merupakan tahapan memilih dan menambahkan data yang diperoleh dari objek penelitian. 3) Preprocecing, merupakan proses data awal yang sudah diperoleh, melalui pemilihan data yang lengkap, tepat dan sesuai. 4) Transformation, merupakan perubahan type text ke dalam type yang susuai dengan kebutuhan algoritma terutama penggunaan algoritma C4.5. 5) Data minig, merupakan proses penterjemahan data dimana dilakukan penerapan algoritma yang digunakan dalam pengolahan data. Pada bagian ini disesuaikan langkah pada algoritma C4.5 6) Evaluation dan Interpretation, merupakan tahapan evaluasi dan penterjemahan data yang diperoleh dari algoritma C4.5. 7) Discovered Knowledge, merupakan pemanfaatan hasil data yang telah menjadi rule baru yang akan diimplementasikan, implementasikan dalam visual.

\section{HASIL PENELITIAN DAN PEMBAHASAN}

Pohon keputusan C4.5 yang terbentuk dengan penentuan gain tertinggi dari masing-masing perhitungan node, berdasarkan node yang sudah ditentukan hingga ditemukan hasil klasifikasinya pada Gambar 2

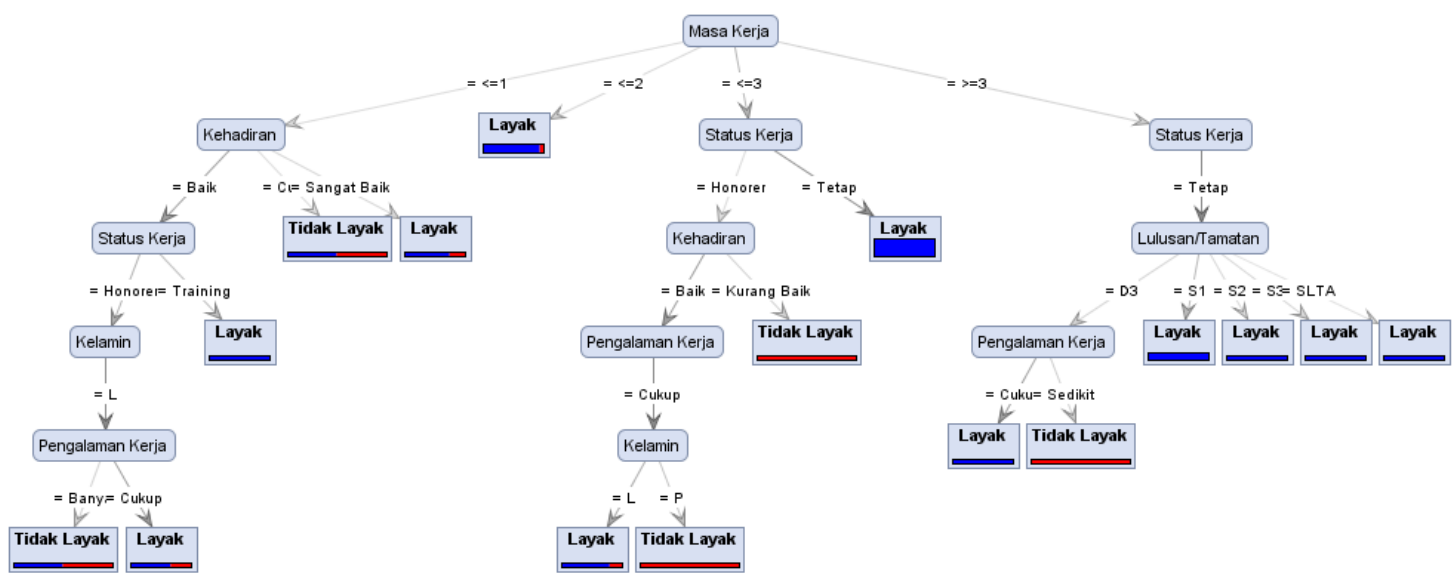

Gambar 2. Model Decision Tree Klasifikasi Kenaikan Jabatan Dengan C4.5

Hasil dari pengujian model yang telah dilakukan yaitu dengam algoritma $\mathrm{C} 4.5$ dilakukan pengujian tingkat akurasi dengan menggunakan confussion matrix dan kurva ROC/AUC (Area Under Cover) 
diperoleh melalui Rapidminer dengan menginput data yang diperoleh dari PT. ABC, berikut hasil evaluasi:

\section{Confusion Matrix}

Perhitungan akurasi data training menggunakan algoritma C4.5. Diketahui data training terdiri dari 202 record data, 202 data diklasifikasikan Layak dan 13 data diprediksi tidak layak, 3 data dinyatakan tidak layak. Class recall untuk kategori layak adalah sebasar $100 \%$ dan class recall untuk kategori true tidak layak sebesar $18,75 \%$.

Tabel 1. Model confusion matrix data training untuk metode $\mathbf{C 4 . 5}$

\begin{tabular}{cccc}
\hline \multicolumn{4}{c}{ Accuracy: 94.05\% +/-2.89\%(mikro:94.04\%) } \\
\hline Pred. layak & True layak & True tidak alayak & Class precision \\
Pred. tidak layak & 202 & 13 & $93.95 \%$ \\
Class recall & 0 & 3 & $100.00 \%$ \\
\hline
\end{tabular}

Dari hasil confusion matrix pada tabel 1, selanjutnya dilakukan perhitungan nilai accuracy, precision, dan recall. Perbandingan nilai accuracy, precision, dan recall yang telah dihitung untuk metode C4.5.

\section{Kurva ROC}

Hasil perhitungan divisualisasikan dengan kurva ROC (Receiver Operating Characteristic) atau AUC (Area Under Curve). ROC memiliki tingkat nilai diagnosa yaitu [1]:

a. Akurasi bernilai $0.90-1.00=$ excellent classification

b. Akurasi bernilai $0.80-0.90=$ good classification

c. Akurasi bernilai $0.70-0.80=$ fair classification

d. Akurasi bernilai $0.60-0.70=$ poor classification

e. Akurasi bernilai $0.50-0.60=$ failure

Hasil yang didapat dari pengolahan ROC untuk algoritma C4.5 dengan menggunakan data training sebesar 0.930 (gambar 3) dengan tingkat diagnosa excellent classification.

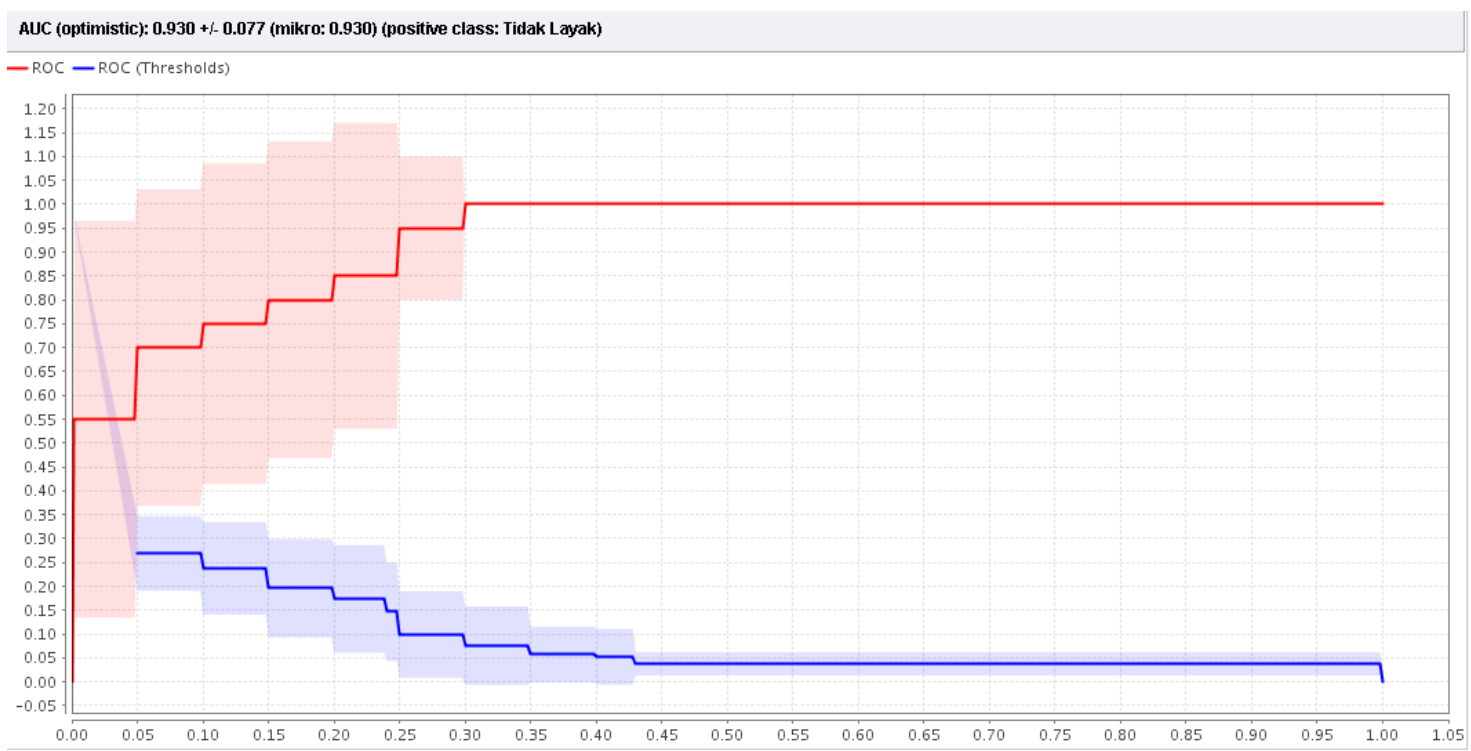

Gambar 3. Kurva ROC Metode C4.5

Dari pohon keputusan pada gambar 2. Model Decision Tree klasifikasi kenaikan jabatan dengan C4.5 dapat dijabarkan sebagai berikut rule yang terbentuk: 


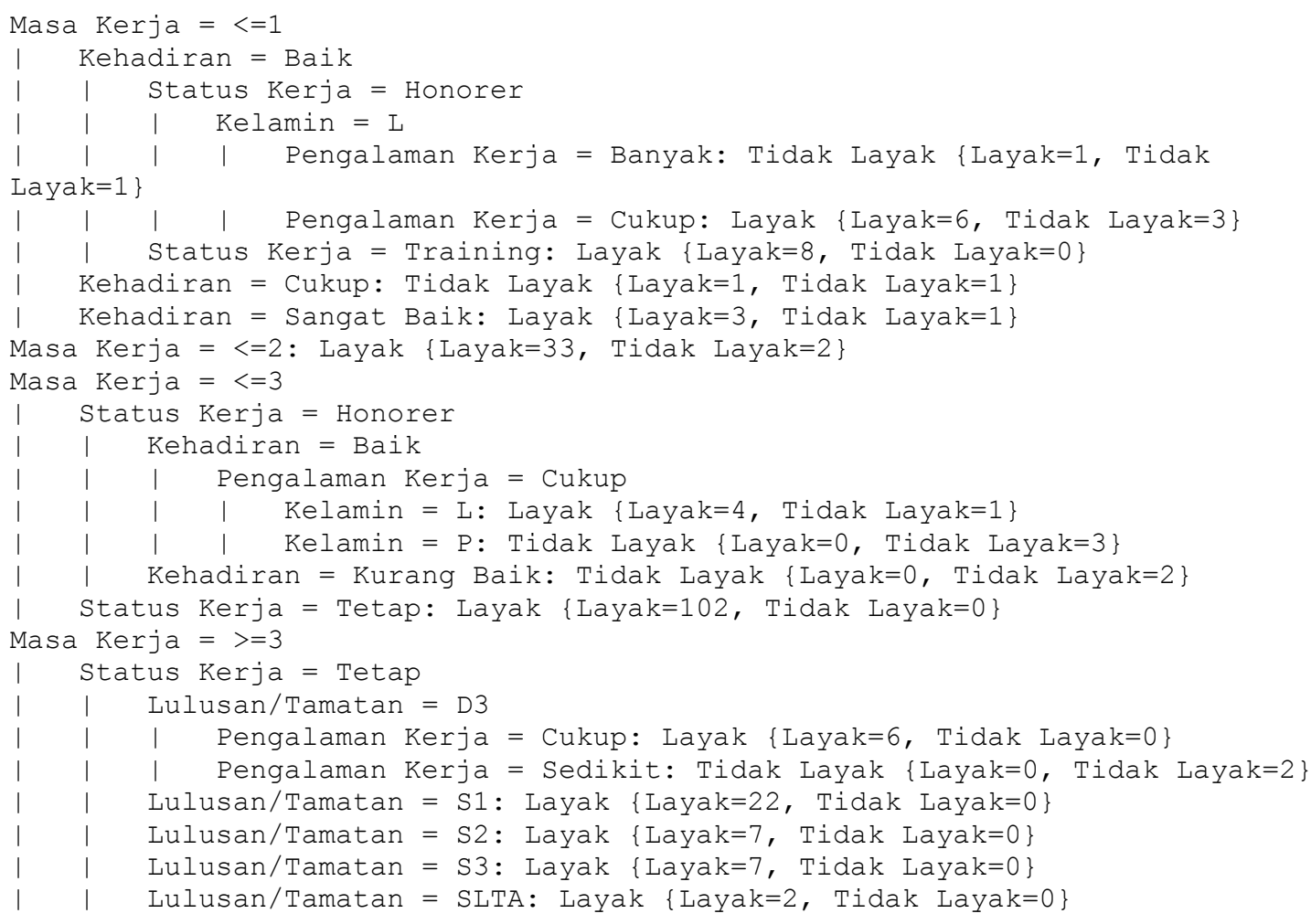

Jika disederhanakan dalam bentuk algoritma untuk dimasukan dalam program aplikasi maka hasilnya sebagai berikut:

Masa Kerja <= 1 maka AND Kehadiran Baik AND Status Kerja Honorer AND Kelamin L AND Pengalaman Kerja Banyak THEN Layak $=1$ tidak layak $=1$

Masa Kerja <= 1 maka AND Kehadiran Baik AND Status Kerja Honorer AND Kelamin L AND Pengalaman Kerja Cukuk THEN Layak $=6$ tidak layak $=3$

Masa Kerja <= 1 maka AND Kehadiran Baik AND Status Kerja Training THEN Layak = 8 tidak layak = 0

Masa Kerja <= 1 maka AND Kehadiran Cukup THEN Layak = 1 tidak layak = 1

Masa Kerja <= 1 maka AND Kehadiran sangat Baik THEN Layak = 3 tidak layak = 1

Masa Kerja $<=2$ THEN Layak 33 Tidak Layak 2

Masa Kerja <=3 AND Status Kerja Honorer AND Kehadiran Baik AND Pengalaman Kerja Cukup AND Kelamin L THEN Layak $=4$ Tidak Layak $=1$

Masa Kerja <=3 AND Status Kerja Honorer AND Kehadiran Baik AND Pengalaman Kerja Cukup AND Kelamin P THEN Layak = 0 Tidak Layak $=3$

Masa Kerja <=3 AND Status Kerja Honorer AND Kehadiran Kurang Baik THEN Layak = 0 Tidak Layak $=2$

Masa Kerja <=3 AND Status Kerja Tetap THEN Layak = 102 Tidak Layak $=2$

Masa Kerja >= 3 AND Status Kerja Tetap AND Lulusan/Tamatan D3 AND Pengalaman Kerja Cukup THEN Layak $=6$ tidak layak 0

Masa Kerja >= 3 AND Status Kerja Tetap AND Lulusan/Tamatan D3 AND Pengalaman Kerja Sedikit THEN Layak $=0$ Tidak Layak 2

Masa Kerja >= 3 AND Status Kerja Tetap AND Lulusan/Tamatan S1 THEN Layak = 22 Tidak Layak 0

Masa Kerja >= 3 AND Status Kerja Tetap AND Lulusan/Tamatan S2 THEN Layak $=7$ Tidak Layak 0

Masa Kerja >= 3 AND Status Kerja Tetap AND Lulusan/Tamatan S3 THEN Layak $=7$ Tidak Layak 0

Masa Kerja >= 3 AND Status Kerja Tetap AND Lulusan/Tamatan SLTA THEN Layak = 2 Tidak Layak 0

\section{KESIMPULAN}

Akurasi data dapat diklasifikasikan sebagai excellent classification nilai yang di peroleh 0.930 sehingga rule yang dihasilkan dapat diterapkan dan digunakan dalam perusahaan sebagai acuan dalam menentukan kenaikan jabatan karyawan. 


\section{DAFTAR PUSTAKA}

[1] Gorunescu, Florin (2011). Data Mining: Concepts, Models, and Techniques. Verlag Berlin Heidelberg: Springer

[2] Han, J.,\& Kamber, M. 2006. Data Mining Concept and Tehniques. San Fransisco: Morgan Kauffman.

[3] Larose, D. T. 2005. Discovering Knowledge in Data. New Jersey: John Willey \& Sons, Inc.

[4] Maimon, Oded \& Rokach, Lior. 2005. Data Mining and Knowledge Discovey Handbook. New York: Springer

[5] Sumathi, \& S., Sivanandam, S.N. 2006. Introduction to Data Mining and its Applications. Berlin Heidelberg New York: Springer

[6] Witten, I. H., et al. 2011. Data Mining: Practical Machine Learning and Tools. Burlington: Morgan Kaufmann Publisher.

[7] Karismariyanti, Magdalena. 2011. Jurnal: Simulasi Pendukung Keputusan Beasiswa menggunakan Metode Composite Performance Index. Jurnal Teknologi Informasi Vol. 1, No. 2, November 2011 